\title{
Electrochemical Reduction and Voltammetric Determination of Diloxanide Furoate in Non-Aqueous Medium
}

\author{
André L. Santos, Regina M. Takeuchi and Nelson R. Stradiotto* \\ Instituto de Química, Universidade Estadual Paulista, Av. Francisco Degni s/n, 14800-900 Araraquara - SP, Brazil
}

\begin{abstract}
A redução eletroquímica do Furoato de Diloxanida (FD) em acetonitrila sobre um eletrodo de carbono vítreo foi estudada neste trabalho. Foi observado que o FD é reduzido após uma transferência reversível de um elétron seguida por uma reação química irreversível, diagnosticada, como uma ruptura de uma ligação C-Cl. A redução do FD foi estudada por voltametria de varredura linear (LSV), pulso diferencial (DPV) e onda quadrada (SWV). Curvas analíticas foram obtidas usando todas as técnicas voltamétricas estudadas. Para a técnica de LSV obteve-se um intervalo linear (LR) de 5,0 x 10-4 a 1,0 x 10-2 $\mathrm{mol} \mathrm{L}^{-1}$, com limite de detecção (DL) de $1,5 \times 10^{-4} \mathrm{~mol} \mathrm{~L}^{-1} \mathrm{e}$ sensibilidade (S) de $2,1 \times 10^{4} \mu \mathrm{A} \mathrm{mol}^{-1} \mathrm{~L}$. Os parâmetros analíticos obtidos com a técnica de DPV foram: $\mathrm{LR}=5,0 \times 10^{-4} \mathrm{a} 2,2 \times 10^{-3} \mathrm{~mol} \mathrm{~L}^{-1}, \mathrm{DL}=7,8 \times 10^{-5} \mathrm{~mol} \mathrm{~L}^{-1}, \mathrm{~S}=3,7 \times 10^{4} \mu \mathrm{A} \mathrm{mol} \mathrm{m}^{-1} \mathrm{~L}$. Para a técnica de $S W V$ foram obtidos os seguintes parâmetros analíticos $\mathrm{LR}=7,5 \times 10^{-6} \mathrm{a} 1,2 \times 10^{-3} \mathrm{~mol}$ $\mathrm{L}^{-1}, \mathrm{DL}=5,5 \times 10^{-6} \mathrm{~mol} \mathrm{~L}^{-1}$ e $\mathrm{S}=2,8 \times 10^{5} \mu \mathrm{A} \mathrm{mol}^{-1} \mathrm{~L}$. Assim, a técnica de SWV foi a mais sensível, podendo ser empregada para a quantificação de FD em baixos níveis de concentração. Métodos estatísticos foram utilizados para avaliar o procedimento analítico, recuperações próximas a $100 \%$ e desvios padrão relativos inferiores a 5,0\% (N=5) foram obtidos. Através do teste-t verificou-se que não há evidências de erros sistemáticos em nenhuma das técnicas estudadas.
\end{abstract}

The electrochemical reduction of diloxanide furoate (DF) in acetonitrile on glassy carbon electrode was studied in this work. It was observed that DF is reduced after a reversible oneelectron transfer followed by an irreversible chemical reaction, diagnosed as $\mathrm{C}-\mathrm{Cl}$ bond cleavage. Its reduction was followed by linear (LSV), differential pulse (DPV) and square wave voltammetry (SWV). Analytical curves were obtained for DF determination using all the investigated voltammetric techniques. For LSV was obtained a linear range (LR) from $5.0 \times 10^{-4}$ to $1.0 \times 10^{-2}$ mol L-1, with detection limit (DL) of $1.5 \times 10^{-4} \mathrm{~mol} \mathrm{~L}^{-1}$ and sensitivity (S) of $2.1 \times 10^{4} \mu \mathrm{A} \mathrm{mol}^{-1} \mathrm{~L}$. The analytical parameters obtained by DPV were: $\mathrm{LR}=5.0 \times 10^{-4}$ to $2.2 \times 10^{-3} \mathrm{~mol} \mathrm{~L}^{-1}$, DL $=7.8$ $\times 10^{-5} \mathrm{~mol} \mathrm{~L}^{-1}, \mathrm{~S}=3.7 \times 10^{4} \mu \mathrm{A} \mathrm{mol}{ }^{-1} \mathrm{~L}$. For SWV were obtained a $\mathrm{LR}=7.5 \times 10^{-6}$ to $1.2 \times 10^{-3}$ mol L ${ }^{-1}, \mathrm{DL}=5.5 \times 10^{-6} \mathrm{~mol} \mathrm{~L}^{-1}$ and $\mathrm{S}=2.8 \times 10^{5} \mu \mathrm{A} \mathrm{mol}^{-1} \mathrm{~L}$. Thus, the SWV was the most sensible technique, which can be used for DF determination at low concentration levels. Statistics methods were used to evaluate the analytical procedure, where recovery around to $100 \%$ was obtained for all voltammetric techniques. Relative standard deviations were lower than $5.0 \%$ $(\mathrm{N}=5)$. The obtained $\mathrm{t}$ values evaluating all the three voltammetric methods were less than the tabulated ones, indicating that there are no evidences of systematic error.

Keywords: diloxanide furoate, amoebiasis, voltammetric determination

\section{Introduction}

Amoebiasis is an infectious disease caused by protozoan parasite Entamoeba histolytica and it is a public health problem in developing countries. According to the Word Health Organization, ${ }^{1}$ amoebiasis is responsible for up to 100,000 deaths per year throughout the world. The incidence of amoebiasis is high in developing countries, where is common the establishment

* e-mail: nrstradi@iq.unesp.br of marginal communities coexisting in environments that present a debilitated sanitary infrastructure. Thus, amoebiasis is endemic in countries of Asia, Africa and South America, being included in the group of the called tropical diseases.

Diloxanide furoate (DF), a chloroacetamide derivative drug (Figure 1), is widely used in the treatment of amoebiasis. It acts mainly in the bowel lumen of the intestine, being, therefore, effective in the treatment of intestinal amoebiasis. DF presents high cure efficiency and 


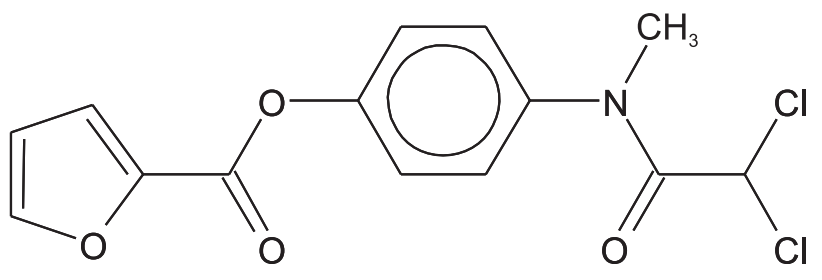

Figure 1. DF molecular structure.

it is considered a safe drug which main adverse effects associates to DF are restricted to gastrointestinal discomforts and excessive flatulence. ${ }^{2}$

Few analytical methods are described in the literature for DF determination. The official method proposed for its determination is based on potentiometric titration in nonaqueous medium. ${ }^{3}$ Alternative methodologies have been also proposed in the literature, including chromatographic ${ }^{4}$ and spectrophotometric methods. ${ }^{5-7}$

The understanding of the redox mechanisms of compounds with pharmacological activity has been very helpful, since the most of metabolic pathway involving these compounds are based on redox reactions. Therefore, electrochemical techniques could play an important role in the study of pharmacologically active compounds. In addition, such techniques have been successful used to develop new electroanalytical methods for determination of these compounds in biological fluids or dosage forms in a rapid, simple and accuracy way. Although the relevance of electrochemical techniques is discussed in literature, ${ }^{8}$ there are no works in the literature about electrochemical behavior of DF.

In this context, the objective of the present work is to study the electrochemical behavior of the DF in acetonitrile on glassy carbon electrode with the aim to evaluate the possibilities of the use of electroanalytical techniques for the DF quantification.

\section{Experimental}

DF standard solutions were prepared by dissolution of diloxanide furoate (Sigma, 99.9\%) in acetonitrile grade HPLC (J. T. Baker). All the electrochemical measurement had been carried out in acetonitrile, using tetrabutylammonium tetrafluorborate ( $\mathrm{TBABF}_{4}$, Eastman) as supporting electrolyte.

Electrochemical experiments were carried out with an EG\&G PAR potentiostat/galvanostat model 173, by using a conventional electrochemical cell containing a $3.0 \mathrm{~mm}$ diameter glassy carbon working electrode, an $\mathrm{Ag} / \mathrm{AgCl}$ saturated reference electrode and a platinum wire auxiliary electrode. Nitrogen was bubbled through the solution for $15 \mathrm{~min}$ before each measurement. The working electrode surface was renewed by polishing with $0.3 \mu \mathrm{m}$ alumina.

Controlled potential electrolyses were carried out in a three-compartment cell with the cathodic and anodic compartments separated by a porous glass plate. The electrodes system consists of a $0.7 \times 1.6 \mathrm{~cm}$ glassy carbon plate as working electrode, a $2.0 \times 2.0 \mathrm{~cm}$ Pt gauze as auxiliary electrode, and an $\mathrm{Ag} / \mathrm{AgCl}$ saturated reference electrode. During all electrolyses, a nitrogen flow was kept in the electrochemical cell to remove dissolved oxygen and to promote the solution stirring.

\section{Results and Discussion}

Due the poor solubility of DF in aqueous solutions, all the voltammetric measurements were carried out by using the acetonitrile/TBABF 4 system, which promotes completely solubilization of the drug and presents a larger potential window. The DF voltammetric behavior in acetonitrile on glassy carbon electrode exhibited a single well-defined cathodic voltammetric peak at potential of $\mathrm{E}_{\mathrm{p}}=-2.0 \mathrm{~V} v s . \mathrm{Ag} / \mathrm{AgCl}_{\text {sat }}$ at scan rate $(v)$ of $100 \mathrm{mV} \mathrm{s}^{-1}$. Figure 2, presents the cyclic voltammograms registered in absence and presence of $2.0 \mathrm{mmol} \mathrm{L}^{-1} \mathrm{DF}$ solution in the interval of -1.4 to $-2.3 \mathrm{~V} v s$. $\mathrm{Ag} / \mathrm{AgCl}_{\text {sat }}$.

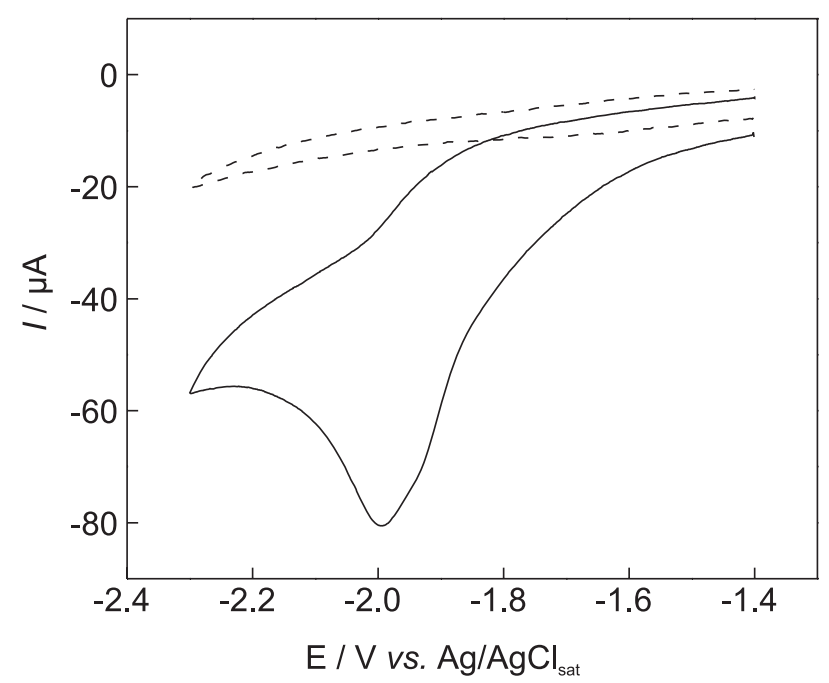

Figure 2. Cyclic voltammograms registered in $0.1 \mathrm{~mol} \mathrm{~L}^{-1} \mathrm{TBABF}_{4} /$ acetonitrile at $100 \mathrm{mV} \mathrm{s}^{-1}$. (‥) Absence of DF. (一) Presence of 2.0 mmol L-1 DF solution.

The absence of an anodic peak in the reverse scan suggests that the DF reduction involves an irreversible electron-transfer or that the electrodic process is complicated by a coupled chemical reaction. A linear relationship was verified between the peak current $\left(i_{p}\right)$ and the square root of scan rate, indicating a diffusion controlled electrode process. The corresponding 
voltammetric parameters obtained at different $v$ values are shown in Table 1. The current function $\left(\mathrm{i}_{\mathrm{p}} / v^{1 / 2}\right)$ increases with the scan rate, indicating the presence of a coupled chemical reaction. For a totally irreversible electron-transfer process, a linear relationship between $\ln \mathrm{i}_{\mathrm{p}}$ and $\left(\mathrm{E}_{\mathrm{p}}-\mathrm{E}_{1 / 2}\right)$ determined at different scan rates must be observed ${ }^{8}$ this relationship was not verified in the carried out studies. This result gives evidences that the absence of the reverse peak in the cyclic voltammograms registered in presence of DF (Figure 2) could be attributed to a fast-coupled chemical reaction that consumes the product generated after the electrontransference. The $\mathrm{E}_{\mathrm{p}}$ values are shifting toward more negative potentials by about $30 \mathrm{mV}$ for a ten-fold increase in $v$, as also shown in Table 1, clearly suggesting the behavior expected for $\mathrm{E}_{\mathrm{r}} \mathrm{C}_{\mathrm{i}}$ mechanism. ${ }^{8}$ The reversible electron transfer is also confirmed when $\mathrm{E}_{\mathrm{p}}$ becomes practically independent of $v$ at values higher than $150 \mathrm{mV} \mathrm{s}^{-1}$. At high scan rates values, the coupled chemical reaction influence on the electron transfer is minimized, and the global electrodic process approaches to the simple reversible system, presenting $E_{p}$ independent of $v$.

Table 1. Voltammetric parameters determined for reduction of 2.0 $\mathrm{mmol} \mathrm{L}^{-1} \mathrm{DF}$ in $0.1 \mathrm{~mol} \mathrm{~L}^{-1} \mathrm{TBABF}_{4}$ /acetonitrile on glassy carbon electrode

\begin{tabular}{ccccc}
\hline$v /\left(\mathrm{mV} \mathrm{s}^{-1}\right)$ & $\mathrm{i}_{\mathrm{p}} / \mu \mathrm{A}$ & $\mathrm{E}_{\mathrm{p}} / \mathrm{V}$ & $\mathrm{E}_{\mathrm{p}}-\mathrm{E}_{\mathrm{p} / 2} / \mathrm{mV}$ & $\begin{array}{c}\mathrm{i}_{\mathrm{p}} / v^{1 / 2} / \\
\left(\mu \mathrm{mV}^{-1 / 2} \mathrm{~s}^{1 / 2}\right)\end{array}$ \\
\hline 10 & 7.3 & 1.95 & 97.0 & 2.3 \\
20 & 12.2 & 1.97 & 102 & 2.7 \\
50 & 24.4 & 1.98 & 106 & 3.4 \\
100 & 42.5 & 1.99 & 111 & 4.2 \\
200 & 64.5 & 2.00 & 108 & 4.6 \\
300 & 82.2 & 2.00 & 102 & 4.7 \\
400 & 104 & 2.00 & 96.0 & 5.2 \\
500 & 114 & 2.01 & 101 & 5.0 \\
\hline
\end{tabular}

The square wave voltammograms obtained in $2.0 \mathrm{x}$ $10^{-4} \mathrm{~mol} \mathrm{~L}^{-1} \mathrm{DF}$ confirms the reversibility of DF reduction, as shown in Figure 3. The anodic peak occurrence on the reverse voltammogram indicates that the process involves a reversible electron transfer followed by a chemical reaction, which is suppressed in the experimental conditions adopted to SWV, where a very high scan rate $\left(2.0 \mathrm{~V} \mathrm{~s}^{-1}\right)$ is used.

Controlled potential electrolyses carried out at -2.35 $\mathrm{V} v s . \mathrm{Ag} / \mathrm{AgCl}_{\text {sat }}$ for $2.0 \mathrm{mmol} \mathrm{L}^{-1} \mathrm{DF}$ in acetonitrile were used as coulometric and preparative ending. Electrolyses were performed up to complete reduction of DF, which was followed by the total disappearance of the characteristic cathodic peak of DF reduction, using

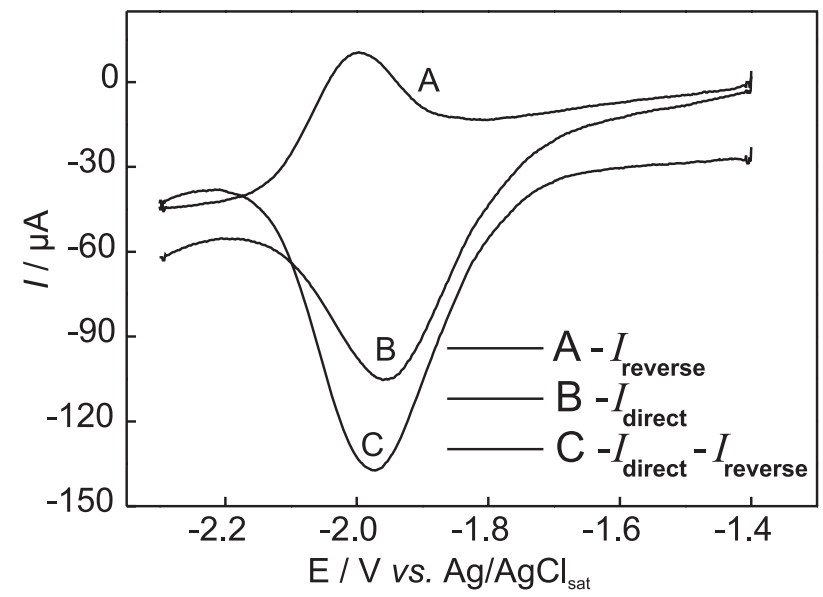

Figure 3. Square wave voltammograms registered in $0.1 \mathrm{~mol} \mathrm{~L}^{-1}$ $\mathrm{TBABF}_{4} /$ acetonitrile in presence of $2.0 \times 10^{-4} \mathrm{~mol} \mathrm{~L}^{-1} \mathrm{DF}$ solution. Experimental conditions $\mathrm{f}=400 \mathrm{~Hz}, \mathrm{D} ð \mathrm{E}=100 \mathrm{mV}, \mathrm{SI}=5.0 \mathrm{mV}$.

cyclic voltammograms registered before and after each electrolysis. The electrolyses were carried out in triplicate and the results indicates average values of $n=$ $1.3 \pm 0.1$, confirming that the number of electrons involved in DF reduction is equal to 1.0.

According with the literature, ${ }^{9-11}$ the $\alpha$-halo carbonyl compounds reduction involves $\mathrm{C}$-halogen bond cleavage and the formation of their dehalogenated compound. Casadei et al. ${ }^{12}$ had demonstrated that the electrochemical reduction of several haloacetamides in dimetilformamide is marked by a cathodic peak at -2.0 $\mathrm{V}$ vs. SCE, involving a $\mathrm{C}-\mathrm{Cl}$ bond rupture, chloride formation and the respective carbanion. After this, condensation/dimerization reactions can occur leading to a complex reaction pathway.

In order to check the occurrence of $\mathrm{C}-\mathrm{Cl}$ bond cleavage in the DF reduction, the product of electrolysis was analyzed by linear sweep voltammetry. Successive additions of $1.0 \times 10^{-2} \mathrm{~mol} \mathrm{~L}^{-1}$ tetrabutylammonium chloride in electrolyzed solution were carried out and the voltammograms recorded. The linear sweep voltammograms registered for DF electrolyzed solution have shown a voltammetric peak at $2.34 \mathrm{~V} v s . \mathrm{Ag} / \mathrm{AgCl}_{\text {sat }}$ and complete disappearance of reductive peak at -2.0 $\mathrm{V} v s . \mathrm{Ag} / \mathrm{AgCl}_{\text {sat }}$ related to $\mathrm{DF}$ reduction. Previous studies of the electrochemical behavior of tetrabutylammonium chloride, showed the same anodic voltammetric peak with $\mathrm{E}_{\mathrm{p}}=2.34 \mathrm{~V} v s . \mathrm{Ag} / \mathrm{AgCl}_{\text {sat }}$, which can only be associated to the chloride electrooxidation, because the chloride salt cation is the same of the support electrolyte. These results indicate that the DF reduction process probably occurs by $\mathrm{C}-\mathrm{Cl}$ bond cleavage, in an analog way that others halogenated compounds already reported in literature. The successive additions of 


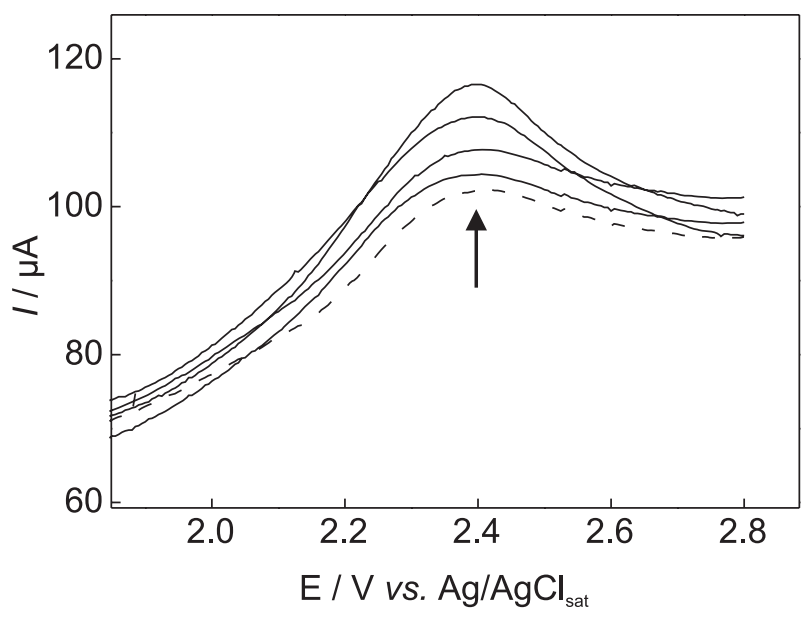

Figure 4. Linear sweep voltammograms registered in $0.1 \mathrm{~mol} \mathrm{~L}^{-1}$ $\mathrm{TBABF}_{4}$ / acetonitrile at $100 \mathrm{mV} \mathrm{s}^{-1}$. (*).) Electrolyzed solution. (一) Successive additions of $250 \mu \mathrm{L}$ of $1.0 \times 10^{-2} \mathrm{~mol} \mathrm{~L}^{-1}$ tetrabutylammonium chloride solution.

tetrabutylammonium chloride solution to the remaining product of electrolyses allowed to quantify the $\mathrm{Cl}^{-}$ liberated during the electrolyses. Figure 4 presents the linear sweep voltammograms registered in electrolyzed solution and in this same solution after successive additions of tetrabutylammonium chloride.

From Figure 4, a linear relationship from $\mathrm{i}_{\mathrm{p}} v s . \mathrm{Cl}^{-}$ concentration was observed, according to the equation: $\mathrm{i}_{\mathrm{p}}=11.6+14.5 \mathrm{C}_{\mathrm{Cl}-}$, with linear correlation coefficient of 0.998 . From this relationship, it was possible to verify that after electrolysis of $2.0 \mathrm{mmol} \mathrm{L}^{-1} \mathrm{DF}$ during $120 \mathrm{~min}$, the $\mathrm{Cl}^{-}$concentration existing in the electrolyzed solutions was $(8.6 \pm 0.7) \times 10^{-4} \mathrm{~mol} \mathrm{~L}^{-1}$ corresponding to $43.5 \% \pm 4.0 \%(\mathrm{~N}=3)$, of the initial DF concentration. This result confirms that the DF reduction occurs via $\mathrm{C}-\mathrm{Cl}$ bond cleavage; forming chloride, which could be suffering parallel reaction with others species generated during the electrolysis.

The studies of DF quantification were carried out using three voltammetric techniques: Linear Sweep voltammetry (LSV), Differential Pulse voltammetry (DPV) and Square Wave Voltammetry (SWV). Initially, it was carried out the optimization of experimental parameters for each voltammetric technique investigated. Thus, for LSV it was chosen the scan rate of $100 \mathrm{mV} \mathrm{s}^{-1}$ as the best value for analysis. For DPV, the optimized parameters were: $v=10 \mathrm{mV} \mathrm{s}^{-1}$, pulse amplitude $(\Delta \mathrm{E})$ of $100 \mathrm{mV}$ and pulse width of $5.0 \mathrm{~ms}$. For SWV the optimized parameters were: frequency (f) of $400 \mathrm{~Hz}, \Delta \mathrm{E}$ of $100 \mathrm{mV}$ and scan increment (SI) of $5.0 \mathrm{mV}$, these parameters give a scan rate of $2.0 \mathrm{~V} \mathrm{~s}^{-1}$. The voltammograms registered under optimized conditions for each technique were then utilized to build analytical curves testing DF concentrations from $7.5 \times 10^{-6}$ to $1.0 \times 10^{-2} \mathrm{~mol} \mathrm{~L}^{-1}$.
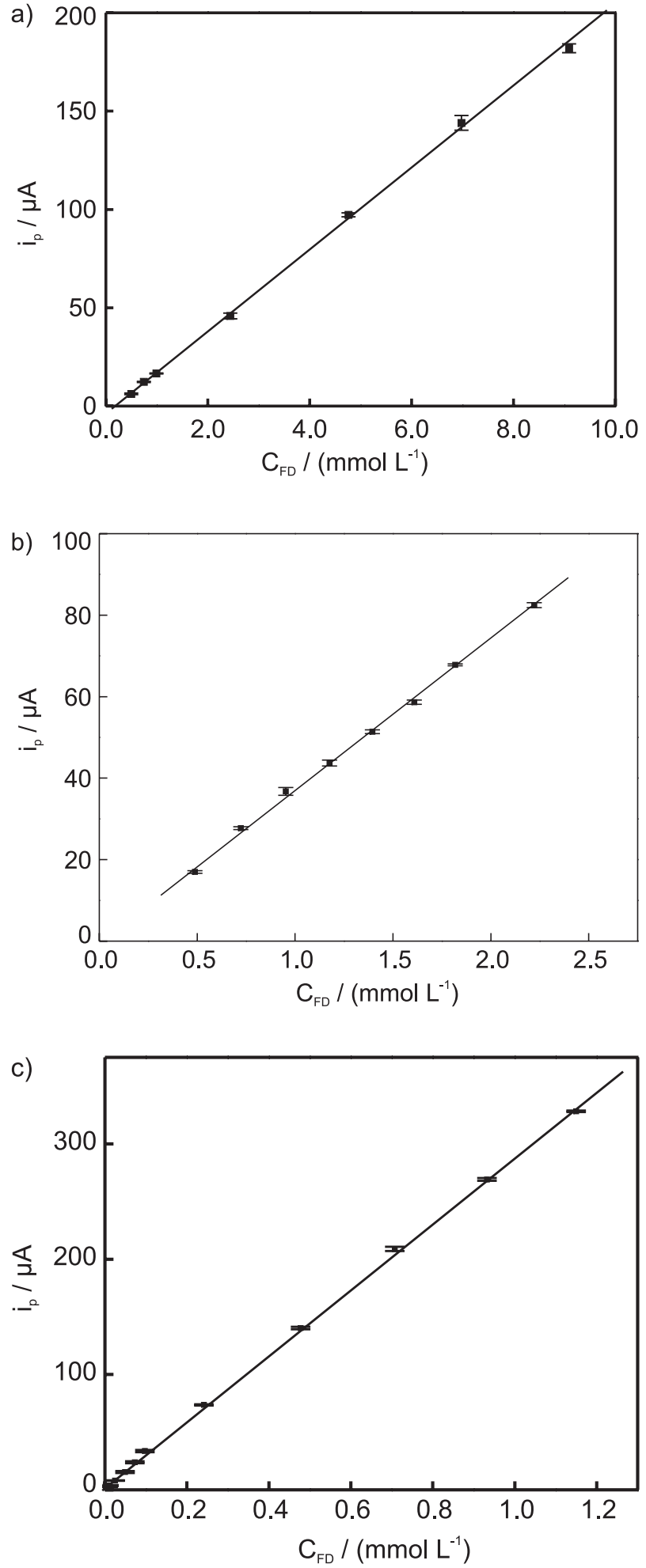

Figure 5. a) Analytical curve obtained by LSV, experimental conditions: $v=100 \mathrm{mV} \mathrm{s}^{-1}$. Linearity according to equation: $\mathrm{i}_{\mathrm{p}}(\mu \mathrm{A})=-1.6$ $+2.1 \times 10^{4} \mathrm{C}_{\mathrm{FD}}\left(\mathrm{mol} \mathrm{L}^{-1}\right), \mathrm{R}=0.9995$. b) Analytical curve obtained by DPV, experimental conditions: $v=10 \mathrm{mV} \mathrm{s}^{-1} . \Delta \mathrm{E}=100 \mathrm{mV}$, pulse width $=5.0 \mathrm{~ms}$. Linearity according to equation: $\mathrm{i}_{\mathrm{p}}(\mu \mathrm{A})=$ $-0.51+3.7 \times 10^{4} \mathrm{C}_{\mathrm{FD}}\left(\mathrm{mol} \mathrm{L}^{-1}\right), \mathrm{R}=0.9994$. c) Analytical curve obtained by SWV, experimental conditions $\mathrm{f}=400 \mathrm{~Hz}, \Delta \mathrm{E}=100$ $\mathrm{mV}, \mathrm{SI}=5.0 \mathrm{mV}$. Linearity according to equation: $\mathrm{i}_{\mathrm{p}}(\mu \mathrm{A})=0.28+$ $2.8 \times 10^{5} \mathrm{C}_{\mathrm{FD}}\left(\mathrm{mol} \mathrm{L}^{-1}\right), \mathrm{R}=0.998$. 
Graphs of the corresponding values of peak current in function of DF concentration for LSV, DPV and SWV are shown, respectively, in Figure 5a, 5b and 5c.

Good linearity was obtained for all analytical curves, presenting linear correlation coefficients superior to 0.999, indicating that DF can be determined by LSV, DPV or SWV. All analytical curves were carried out in triplicate, being observed good repeatability of the experimental measurements. Theses results suggest that the voltammetric techniques are potentially applicable for DF determination. Table 2 exhibits the main analytical parameters obtained for all the voltammetric techniques utilized.

Table 2 shows that all voltammetric techniques utilized presented a large linear range, high sensitivity (S), and low detection limit (DL), evaluated by the equation: $\mathrm{DL}=$ $3 \mathrm{sd} / \mathrm{S}$, where sd is equivalent to the standard deviation of the average of the signal of eight measurements of the blank in the peak potential of DF reduction. Table 2 analysis indicates that SWV presented lower detection limit and higher sensitivity in relation to LSV or DPV, and could be chosen for DF determination at low concentration level. The best analytical performance was obtained using SWV, due to considerable contribution of the anodic component in the resultant current as shown in Figure 3.

Table 2. Analytical parameters obtained for DF determination via LSV, DPV and SWV voltammograms recorded under optimized conditions in acetonitrile on glassy carbon electrode

\begin{tabular}{lccc}
\hline Technique & $\begin{array}{c}\text { Linear range } \\
\left(\mathrm{mol} \mathrm{L}^{-1}\right)\end{array}$ & $\begin{array}{c}\text { Sensitivity } \\
(\mu \mathrm{A} \mathrm{L} \mathrm{mol}\end{array}$ & $\begin{array}{c}\text { Detection limit } \\
\left(\mathrm{mol} \mathrm{L}^{-1}\right)\end{array}$ \\
\hline LSV & $5.0 \times 10^{-4}-1.0 \times 10^{-2}$ & $2.1 \times 10^{4}$ & $1.5 \times 10^{-4}$ \\
DPV & $5.0 \times 10^{-4}-2.2 \times 10^{-3}$ & $3.7 \times 10^{4}$ & $7.8 \times 10^{-5}$ \\
SWV & $7.5 \times 10^{-6}-1.2 \times 10^{-3}$ & $2.8 \times 10^{5}$ & $5.5 \times 10^{-6}$ \\
\hline
\end{tabular}

The analytical performance of the three used voltammetric techniques was evaluated by the merit figures: recovery test, t-test and relative standard deviation. For the accomplishment of these tests, standards of the drug were prepared and these were submitted to determination using standard addition method. The average value (5 repetitions) of concentration obtained for each technique was then submitted to t-test. Table 3 presents the statistic results obtained for LSV, DPV and SWV techniques.

Table 3 shows that all used voltammetric techniques had presented recovery percentages close to $100 \%$. The relative standard deviation values were always lesser than $5.0 \%$, indicating that the voltammetric techniques present high repeatability. The obtained values of $\mathrm{t}$ had not exceeded the critical value of $t$, indicating that there are no evidences of systematic error in the results obtained by any voltammetric techniques investigated.

\section{Conclusions}

The study of the DF electrochemical behavior supplies evidences that the DF reduction involves a reversible transference of one electron followed by a coupled chemical reaction, according to an $\mathrm{E}_{\mathrm{r}} \mathrm{C}_{\mathrm{i}}$ mechanism. Controlled potential electrolyses confirm that the number of electrons transferred is 1.0, and chloride formation was observed in the electrolyzed product, suggesting that the DF reduction occurs by $\mathrm{C}-\mathrm{Cl}$ bond cleavage, as well as reduction of others halogenated compounds already reported in literature.

The voltammetric techniques have revealed great analytical potentiality for DF determination in nonaqueous solutions. The techniques of LSV and DPV have presented similar sensitivity values and detection limit, being that LSV presents the advantage, in relation to DPV, of being faster and have presented a larger linear interval in function of the DF concentration. The SWV was showed the best analytical performance, being the most sensible technique, which can be used for DF determination at low concentration levels.

\section{Acknowledgments}

The authors are grateful to CAPES and FAPESP for financial support.

Table 3. Statistic evaluation of the results obtained for DF determination using LSV, DPV and SWV. Results obtained from voltammograms recorded under optimized conditions in acetonitrile on glassy carbon electrode

\begin{tabular}{cccccc}
\hline Technique & $\begin{array}{c}\text { Claimed } \\
\text { concentration } \\
\left(\mathrm{mmol} \mathrm{L}^{-1}\right)\end{array}$ & $\begin{array}{c}\text { Determined } \\
\text { concentration } \\
\left(\mathrm{mmol} \mathrm{L}^{-1}\right)\end{array}$ & $\begin{array}{c}\text { Relative standard } \\
\text { deviation } \\
(\%)\end{array}$ & $\mathrm{t}^{\mathrm{b}}$ & $\begin{array}{c}\text { Recovery } \\
(\%)\end{array}$ \\
\hline LSV & 1.00 & 0.967 & 4.4 & 1.7 & 96.7 \\
DPV & 1.00 & 1.01 & 4.1 & 0.53 & 101.0 \\
SWV & 0.20 & 0.207 & 0.31 & 2.59 & 103.5 \\
\hline
\end{tabular}

average obtained with $\mathrm{N}=5$; ${ }^{\mathrm{b}}$ Critical value of $\mathrm{t}$ for 4 degrees of freedom $(\mathrm{P}=0.05)$ equal to 2.78 . 


\section{References}

1. Bull. W.H.O. 1997, 75, 291.

2. Korolkovas, A.; Burckhalter, J.H.; Química Farmacêutica, Guanabara Koogan: Rio de Janeiro, 1988.

3. The United States Pharmacopeia 26, US Pharmacopeial Convention: Rockville; MD, 2003, p. 624.

4. El-Gizawy, S.M.; Anal. Lett. 1995, 28, 83.

5. Al-Ghanam, S.; Belal, F.; IL Farmaco 2000, 56, 677.

6. Daabees, H.G.; Anal. Lett. 1998, 31,1509.

7. Mohamed, M.Y.; El-Gendy, A.E.; El-Bardicy, M.G.; Tawakkol, M.S.; Ahmad, A.K.S.; Spectroscopy Lett. 1996, 29, 299.
8. Bard, A.J.; Faulkner, L.R.; Electrochemical Methods: Fundamentals and Applications, John Wiley \& Sons: New York, 2001.

9. Fry, A.J.; O’Dea, J. J.; J. Org. Chem. 1975, 40, 3625.

10. Fry, A.J.; J. Org. Chem. 1981, 46, 1490.

11. Dirlam, J.P.; Eberson, L.; Casanova, J.; J. Am. Chem. Soc. 1972, 94, 240.

12. Casadei, M.A.; Di Rienzo, B.; Inesi, A.; Moracci, F.M.; J. Chem. Soc. Perkin Trans. 1 1992, 375.

Received: December 6, 2004 Published on the web: July 07, 2005

FAPESP helped in meeting the publication costs of this article. 